\title{
Determinan Demografi Penggunaan Internet Petani Padi di Indonesia dan Kaitannya Dengan Produktivitas
}

\author{
(Demographic Determinants of Internet Use on Paddy Farmers in Indonesia and the Link of the \\ Usage to the Paddy Yield) \\ Kadir $^{1 *}$, Octavia Rizky Prasetyo ${ }^{2}$ \\ ${ }^{1,2}$ Badan Pusat Statistik, Direktorat Statistik Tanaman Pangan, Hortikultura, dan Perkebunan \\ Jl. Dr. Sutomo No. 6-8 Jakarta \\ Email: kadirsst@bps.go.id
}

\begin{abstract}
ABSTRAK
Penelitian ini bertujuan mengidentifikasi determinan demografi penggunaan internet petani padi di Indonesia dan kaitan antara penggunaan tersebut dengan tingkat produktivitas tanaman padi yang dibudidayakan. Model regresi logistik yang diterapkan pada data hasil Survei Pertanian Antar Sensus (SUTAS) yang dilaksanakan BPS pada 2018 memperlihatkan bahwa penggunaan internet di kalangan petani padi merupakan fenomena petani muda, berpendidikan tinggi, berjenis kelamin laki-laki, dan tinggal di Pulau Jawa. Sayangnya, petani padi dengan kombinasi karakteristik demografi seperti ini hanya mewakili kelompok kecil petani padi Indonesia. Penelitian ini juga menemukan perbedaan yang signifikan pada produktivitas tanaman padi yang dibudidayakan oleh petani pengguna internet dan petani yang tidak menggunakan internet. Produktivitas tanaman padi yang dibudidayakan petani pengguna internet relatif lebih tinggi dibanding petani yang tidak menggunakan internet. Temuan ini merupakan indikasi kuat bahwa penggunaan internet oleh petani padi berdampak signifikan terhadap peningkatan produktivitas tanaman padi yang dibudidayakan petani.
\end{abstract}

Kata kunci: demografi, internet, logistik, padi, produktivitas, regresi, SUTAS

\begin{abstract}
This study aims to identify the demographic determinants of internet use on paddy farmers in Indonesia and the link of the usage to the paddy yield cultivated by the farmers. A logistic regression model implemented on the enumeration results of the Intercensal of Agricultural Survey (SUTAS) carried out by Statistics Indonesia (BPS) in 2018 found that internet use among the paddy farmers is a phenomenon of young farmers, well educated, men and residents of Java Island. Unfortunately, paddy farmers with those combined demographic characteristics only represent a small fraction of the total paddy farmers in Indonesia. This study also pointed out that there is a statistically significant difference in the yield of paddy cultivated by farmers using the internet and non-users. The average yield of internet users is significantly higher than that of non-internet users. This finding is a strong indication that internet use by paddy farmers could have a significant impact on the increase of paddy yield cultivated.
\end{abstract}

Keywords: demographic, internet, logistic, paddy, regression, SUTAS, yield

\section{PENDAHULUAN}

Indonesia menghadapi tantangan permintaan pangan domestik, khususnya beras, yang terus meningkat seiring dengan populasi yang terus tumbuh. Angka konsumsi beras per kapita Indonesia masih cukup tinggi, yakni mencapai $112 \mathrm{~kg}$ per kapita per tahun (BPS, 2019). Tanpa upaya peningkatan kapasitas produksi beras nasional untuk mengimbangi tekanan pertumbuhan jumlah penduduk, Indonesia akan sangat bergantung pada impor beras dari negara lain. Secara teknis, ada dua hal yang dapat dilakukan untuk meningkatkan kapasitas produksi beras nasional, yakni melakukan perluasan lahan sawah dan memacu produktivitas (Ruslan, K., 2021). Derasnya laju konversi lahan pertanian, khususnya sawah, dalam dasawarsa terakhir menjadikan peningkatan produktivitas sebagai upaya kunci yang dapat ditempuh oleh pemerintah dalam meningkatkan produktivitas padi nasional.

Sejumlah studi memperlihatkan bahwa akses terhadap teknologi informasi, khususnya internet, berdampak pada produktivitas komoditas pertanian yang dibudidayakan oleh petani (Ruslan, 2021). Hasil studi Kaila \& Tarp (2019) memperlihatkan bahwa petani padi Vietnam yang menggunakan internet memiliki produksi yang lebih tinggi sekitar 6,8 persen dibanding yang tidak menggunakan internet. Hal ini sejalan dengan temuan Khanal et.al (2013) yang memperlihatkan bahwa rumah tangga petani skala kecil yang memiliki akses terhadap internet memiliki pendapatan yang lebih tinggi dibanding petani skala kecil yang tidak memiliki akses terhadap internet untuk kasus Amerika Serikat. Penggunaan internet dapat memberikan 
kesempatan kepada petani untuk memperoleh informasi terkait akses terhadap kredit perbankan, pemasaran hasil pertanian, dan teknik budidaya untuk meningkatkan produksi pertanian (Ruslan, K., 2021; Safitri, 2020). Hasil studi LoPicalo (2021) memperlihatkan bahwa peningkatan tingkat penetrasi internet dalam industri pertanian Amerika Serikat dapat meningkatkan produktivitas jagung dan kedelai masing-masing sekitar 5,5 persen dan 3,6 persen.

Penggunaan internet oleh petani kemungkinan dipengaruhi karakteristik demografi petani, seperti umur dan tingkat pendidikan. Mishra \& Williams (2006) menemukan bahwa akses petani terhadap komputer yang dilengkapi dengan jaringan internet di Amerika Serikat berhubungan positif dengan umur, tingkat pendidikan, dan lokasi regional dari petani. Sementara itu, Hill et al (2008) dan Khanal et.al (2013) menemukan asosiasi negatif antara umur dan penggunaan internet. Simeunović \& Russo (2020) menyatakan bahwa pendidikan sangat penting dalam adopsi teknologi informasi dan komunikasi. Hubungan positif pendidikan dengan akses petani terhadap internet juga terkonfirmasi oleh penelitian Okojie \& FE (2021) di Negeria. Mereka juga menemukan bahwa umur, jenis kelamin, skala usaha tani, jumlah anggota rumah tangga, dan tingkat pendapatan petani juga berpengaruh terhadap akses terhadap internet selain tingkat pendidikan. Penelitian Sekabira et.al (2012) menemukan bahwa penggunaan internet oleh petani di Uganda dipengaruhi oleh jenis kelamin petani, pendidikan, dan luas lahan pertanian yang dibudidayakan. Pengaruh skala pertanian yang diusahakan terhadap adopsi teknologi informasi dan komunikasi juga dikonfirmasi Warren (2003). Hasil studi Khanal et.al (2013) memperlihatkan, selain dipengaruhi oleh umur dan pendidikan petani, akses internet juga dipengaruhi variasi wilayah tempat tinggal petani (region).

Sepengetahuan kami, studi dengan cakupan nasional yang menelaah determinan demografi penggunaan internet petani padi Indonesia dan kaitan penggunaan tersebut dengan level produktivitas belum tersedia. Studi ini ingin menutup kesenjangan tersebut dengan menelaah pengaruh variabel demografi (umur, jenis kelamin, tingkat pendidikan, wilayah tempat tinggal) dan variabel kontrol lainnya (skala usaha tani dan jenis varietas padi yang dibudidayakan) terhadap peluang petani padi untuk mengakses internet. Selain itu, penelitian ini juga menelaah perbedaan rata-rata produktivitas petani padi menurut penggunaan internet. Penelitian ini diharapkan memberi masukan bagi upaya pemerintah dalam meningkatkan penggunaan internet oleh petani padi untuk meningkatkan produktivitas usaha tani padi di Indonesia.

\section{METODE}

Penelitian ini mengelaborasi mikrodata hasil Survei Pertanian Antar Sensus (SUTAS) yang dilaksanakan Badan Pusat Statistik (BPS) pada 2018 secara nasional di 34 provinsi. Mikrodata tersebut memuat 1.349.716 sampel petani yang mengusahakan tanaman padi sawah dan padi ladang sepanjang periode Mei 2017 s.d. April 2018. SUTAS 2018 menggunakan pendekatan rumah tangga. Petani dalam penelitian ini merupakan petani utama (nilai produksi terbesar) pada setiap rumah tangga. Model regresi logistik diaplikasikan pada data yang ada untuk mengidentifikasi variabel demografi yang mempengaruhi peluang petani padi (setiap rumah tangga) menggunakan internet. Model regresi logistik dipilih karena variabel tak bebas dalam penelitian ini (penggunaan internet) merupakan variabel biner (Bogdan \& Biklen, 2007). Model ini merupakan choices model yang didasarkan pada utilitas random atau random utility (Greene, 2002) yang dapat dinyatakan dengan fungsi utilitas (kepuasan) berikut:

$U_{i}=\alpha+x_{i}^{\prime} \beta+\varepsilon_{i}$

Dalam konteks penelitian ini, persamaan (1) memodelkan tingkat kepuasan individu atas pilihan menggunakan internet berdasarkan karakteristik setiap individu $\left(x_{i}^{\prime}\right) . x_{i}^{\prime}$ merupakan sebuah vektor yang memuat karakteristik individu yang terdiri dari umur, jenis kelamin, tingkat pendidikan, jenis varietas padi yang dibudidayakan, wilayah tempat tinggal, dan luas panen selama setahun yang lalu (skala usaha tani). $\beta$ adalah vektor parameter yang akan diestimasi dan $\varepsilon_{i}$ adalah komponen galat. Peluang petani menggunakan internet akan diestimasi berdasarkan karakteristik masing-masing petani. Mengikuti Greene (2002), fungsi logistik dalam penelitian ini dapat dituliskan sebagai berikut:

$$
\operatorname{Prob}(Y=1 \mid X)=\frac{e^{\alpha+x_{i}^{\prime} \beta}}{1+e^{\alpha+x_{i}^{\prime} \beta}}=\Lambda\left(\alpha+x_{i}^{\prime} \beta\right) .
$$

Pada persamaan (2), $Y$ adalah pilihan petani menggunakan internet, yang bernilai 1 ketika petani menggunakan internet dan 0 jika tidak menggunakan internet. Pilihan petani menggunakan internet atau tidak merupakan keputusan yang memaksimalkan tingkat utilitas pada Persamaan (1). Spesifikasi model logit yang digunakan dalam penelitian ini dapat dituliskan sebagai berikut:

$$
y_{i}=\alpha+x_{i}^{\prime} \beta+\varepsilon_{i}
$$


Di mana $y_{i}$ adalah variabel biner penggunaan internet yang bernilai 1 jika petani merupakan pengguna dan 0 jika petani bukan pengguna. $x_{i}^{\prime}$ adalah vektor variabel independen yang secara rinci dijelaskan pada Tabel 1.

Tabel 1. Deskripsi Variabel Penelitian

\begin{tabular}{|c|c|}
\hline \multicolumn{2}{|c|}{$\begin{array}{l}\text { Variabel terikat: Penggunaan internet yang bernilai } 1 \text { jika petani merupakan pengguna dan } 0 \text { jika petani bukan } \\
\text { pengguna }\end{array}$} \\
\hline Variabel bebas: & \\
\hline Jenis Kelamin & $\begin{array}{l}\text { Jenis kelamin petani terdiri dari dua kategori (laki-laki dan perempuan) di mana kelompok } \\
\text { perempuan sebagai kategori referensi. Petani dalam penelitian ini adalah petani utama } \\
\text { (nilai produksi terbesar) di setiap rumah tangga sampel. }\end{array}$ \\
\hline Pendidikan & $\begin{array}{l}\text { Tingkat pendidikan petani berdasarkan pendidikan tertinggi yang ditamatkan. Kategori } \\
\text { referensi adalah tidak sekolah/tidak tamat SD. }\end{array}$ \\
\hline Umur & $\begin{array}{l}\text { Umur petani dalam tahun. Dibedakan menjadi beberapa kelompok, dengan referensi petani } \\
\text { utama dengan umur di bawah } 30 \text { tahun. }\end{array}$ \\
\hline Wilayah & Wilayah tempat tinggal petani yang terdiri dari Jawa dan luar Jawa (kategori referensi). \\
\hline Varietas Padi & $\begin{array}{l}\text { Varietas padi dibedakan menjadi padi ladang, padi sawah hibrida, dan padi sawah inbrida. } \\
\text { Kategori referensi adalah varietas padi lading. }\end{array}$ \\
\hline Luas panen & $\begin{array}{l}\text { Logaritma natural luas panen selama periode Mei } 2017 \text { sampai dengan April } 2018 \text { sebagai } \\
\text { proksi skala usaha tani. }\end{array}$ \\
\hline Produktivitas & $\begin{array}{l}\text { Kuantitas produksi dalam kuintal per hektar selama periode Mei } 2017 \text { sampai dengan April } \\
2018 .\end{array}$ \\
\hline
\end{tabular}

Untuk menelaah apakah penggunaan internet dapat menjelaskan variasi produktivitas, estimasi selang interval rata-rata produktivitas pada kelompok petani yang menggunakan internet dan tidak menggunakan internet akan dilakukan untuk menyelidiki apakah estimasi selang interval masing-masing kelompok petani menurut penggunaan internet saling tumpang tindih atau tidak pada tingkat signifikansi 5 persen. Perbedan distribusi nilai produktivitas antar masing-masing kelompok juga akan dianalisis dengan menampilkan plot kernel density function produktivitas masing-masing kelompok. Fungsi yang akan diestimasi adalah fungsi kernel Epanechnikov (Van Kerm, 2003) sebagai berikut:

$$
\hat{f}_{k}=\frac{1}{h} \sum_{i=1}^{n} K\left(\frac{x-X_{i}}{h}\right)
$$

di mana $h$ adalah bandwidth yang akan menentukan berapa banyak nilai yang dibutuhkan untuk mengestimasi density pada setiap poin. Dalam penelitian ini, nila $h=0,15 . x$ adalah logaritma natural dari produktivitas tanaman padi dan $n$ adalah jumlah sampel.

\section{HASIL DAN PEMBAHASAN}

\section{Karakteristik demografi petani padi}

Secara demografi, sebagian besar petani padi di Indonesia berpendidikan rendah (pendidikan tertinggi yang ditamatkan Sekolah Dasar/SD), berumur di atas 55 tahun, berjenis kelamin laki-laki dan tinggal di Pulau Jawa. Proporsi petani padi dengan pendidikan tertinggi SD mencapai sekitar 71 persen. Proporsi petani padi dengan pendidikan minimal sarjana sangat kecil, yakni di bawah 2 persen. Sementara itu, lebih dari separuh petani padi berumur di atas 50 tahun. Proporsi petani yang berumur 55 tahun ke atas hampir mencapai 40 persen dari total jumlah petani padi, paling tinggi dibandingkan dengan kelompok umur lainnya. Kombinasi pendidikan yang relatif rendah dan umur yang relatif tua dapat menjadi hambatan petani padi dalam penggunaan teknologi informasi, khususnya internet.

Proporsi petani laki-laki mencapai 88,8 persen. Hal ini menunjukkan bahwa budidaya tanaman padi di Indonesia merupakan fenomena laki-laki. Meskipun demikian, proporsi petani perempuan yang mencapai sekitar 11,2 persen memperlihatkan semakin pentingnya peran petani perempuan dalam budidaya tanaman padi di Indonesia. Selain itu, walaupun bukan sebagai petani, kaum perempuan sebetulnya memiliki kontribusi yang cukup besar dalam kegiatan usaha tani, baik sebagai pekerja keluarga maupun buruh tani.

Tingginya proporsi petani di Pulau Jawa terhadap total jumlah petani, yang mencapai sekitar 60,2 persen, mengindikasikan bahwa aktivitas budidaya tanaman padi masih sedikit terkonsentrasi di Pulau Jawa. Menariknya, jika dilihat berdasarkan luas baku lahan sawah, kontribusi Pulau Jawa (47 persen) dan Luar Jawa (53 persen) sebetulnya sedikit berimbang (Ruslan, K., 2021). Hal ini menyiratkan bahwa rata-rata luas lahan sawah yang dibudidayakan petani di Pulau Jawa lebih rendah dibandingkan dengan petani di luar Pulau Jawa. 
Informasi pada Tabel 2 memperlihatkan indikasi kuat bahwa skala usaha budidaya tanaman padi di Indonesia relatif kecil. Rata-rata luas panen dalam setahun untuk petani padi ladang, padi sawah hibrida, dan padi sawah inbrida masing-masing hanya seluas 0,4 hektar, 0,6 hektar, dan 0,6 hektar. Sementara itu, dari sisi produktivitas, satu hektar lahan sawah di Indonesia secara rata-rata hanya mampu menghasilkan kurang dari 5 ton per hektar. Namun demikian, patut diperhatikan produktivitas yang disajikan dalam penelitian ini merupakan hasil pembagian nilai produksi dan luas panen yang diperoleh dari hasil wawancara terhadap petani. Besar kemungkinan angka produktivitas yang lebih kecil dari data resmi yang dipublikasikan BPS ini (BPS, 2021) underestimate mengingat adanya kecenderungan bahwa informasi yang diperoleh dari deklarasi petani (memory recalling) cenderung underestimate (FAO, 2010).

Sebagian besar petani padi membudidayakan padi jenis inbrida, yakni mencapai sekitar 86,2 persen. Yang cukup menarik adalah rendahnya persentase petani yang membudidayakan padi jenis hibrida (7,0 persen) padahal padi jenis ini dapat menghasilkan produktivitas yang lebih tinggi dibandingkan dengan padi jenis lainnya. Hal ini menunjukkan bahwa ruang untuk meningkatkan produktivitas padi nasional masih terbuka lebar melalui penggunaan benih hibrida yang lebih masif oleh petani.

Tabel 2. Karakteristik Petani Padi di Indonesia

\begin{tabular}{|c|c|c|}
\hline $\begin{array}{r}\text { Karakteristik petani } \\
\end{array}$ & Proporsi (\%) & Rata-rata \\
\hline \multicolumn{3}{|l|}{ 1. Produktivitas (kuintal/hektar) } \\
\hline Padi ladang & - & 21,14 \\
\hline Padi sawah hibrida & - & 43,22 \\
\hline Padi sawah inbrida & - & 42,48 \\
\hline \multicolumn{3}{|l|}{ 2. Luas panen (hektar) } \\
\hline Padi ladang & - & 0,43 \\
\hline Padi sawah hibrida & - & 0,58 \\
\hline Padi sawah inbrida & - & 0,62 \\
\hline \multicolumn{3}{|l|}{ 3. Kelompok umur (tahun) } \\
\hline$<30$ & 3,31 & - \\
\hline $30-34$ & 5,76 & - \\
\hline $35-39$ & 9,69 & \\
\hline $40-44$ & 12,12 & - \\
\hline $45-49$ & 14,41 & - \\
\hline $50-54$ & 14,81 & - \\
\hline $55+$ & 39,89 & - \\
\hline \multicolumn{3}{|l|}{ 4. Tingkat pendidikan yang ditamatkan } \\
\hline Tidak sekolah/tidak tamat SD & 25,21 & - \\
\hline SD & 44,96 & - \\
\hline SMP & 14,73 & - \\
\hline SMA & 12,44 & - \\
\hline D1/D2 & 0,32 & - \\
\hline D3 & 0,3 & - \\
\hline $\mathrm{D} 4 / \mathrm{S} 1$ & 1,93 & - \\
\hline $\mathrm{S} 2 / \mathrm{S} 3$ & 0,00 & - \\
\hline \multicolumn{3}{|l|}{ 5. Jenis kelamin } \\
\hline Laki-laki & 88,76 & - \\
\hline Perempuan & 11,24 & - \\
\hline \multicolumn{3}{|l|}{ 6. Wilayah } \\
\hline Jawa & 60,17 & - \\
\hline Luar Jawa & 39,83 & - \\
\hline \multicolumn{3}{|c|}{ 7. Jenis Varietas Padi yang Dibudidayakan } \\
\hline Padi ladang & 6,99 & - \\
\hline Padi sawah hibrida & 6,85 & - \\
\hline Padi sawah inbrida & 86,16 & - \\
\hline
\end{tabular}

\section{Penggunaan internet menurut karakteristik petani padi}

Akses internet pada petani padi relatif rendah. Hal ini tercermin dari proporsi petani padi pengguna internet yang hanya sebesar 10,8 persen dari sekitar 13 juta petani padi di Indonesia. Jika dilihat berdasarkan jenis varietas padi yang dibudidayakan, tingkat penggunaan internet yang paling tinggi terdapat pada rumah tangga padi sawah hibrida dan inbrida dengan proporsi untuk petani padi sawah hibrida dan inbrida masingmasing sebesar 12,1 dan 10,9 persen. Proporsi petani padi ladang yang menggunakan internet hanya sekitar 
7,9 persen. Hal ini dapat dimengerti karena sebagian besar petani padi membudidayakan padi sawah, baik jenis hibrida maupun inbrida.

Secara demografi, tingkat penggunaan internet menurun seiring dengan peningkatan umur petani. Tingkat penggunaan internet yang paling besar terdapat pada kelompok petani muda, yakni petani pada kelompok usia kurang dari 40 tahun. Tingkat penggunaan internet pada petani padi kelompok umur di bawah 30 tahun dan kelompok umur 30-34 tahun masing-masing sebesar 34,0 persen dan 27,8 persen. Padahal mayoritas petani padi berada pada kelompok umur di atas 40 tahun, yakni mencapai lebih dari 80 persen. Proporsi petani berumur di bawah 35 tahun kurang dari 10 persen.

Sebaliknya, tingkat penggunaan internet meningkat seiring dengan peningkatan tingkat pendidikan di mana tingkat penggunaan internet tertinggi terdapat pada petani dengan pendidikan minimal D4/S1 (sarjana). Tingkat penggunaan internet pada petani dengan pendidikan D4/S1 dan S2/S3 masing-masing sebesar 61,3 persen dan 70,8 persen. Sayangnya, proporsi petani yang menamatkan pendidikan sarjana dan pascasarjana sangat kecil. Sementara itu, dari sisi gender, tingkat penggunaan internet pada petani laki-laki cenderung lebih tinggi dibanding petani perempuan.

Dari sisi wilayah, tingkat penggunaan internet pada petani di Pulau Jawa (11,1 persen) cenderung sedikit lebih tinggi dibanding petani di luar Pulau Jawa (10,4 persen). Namun demikian, meskipun perbedaan proporsi petani yang menggunakan internet antara Jawa dan luar Jawa tidak terlalu besar, variasi yang terjadi antar provinsi baik di Jawa maupun luar Jawa cukup besar. Di Pulau Jawa, provinsi dengan proporsi petani pengguna internet yang masuk dalam rentang 10-15 persen adalah Jawa Tengah (11,7 persen), Jawa Timur (12,5 persen), DI Yogyakarta (15 persen), dan DKI Jakarta (35,5 persen).

Tingginya proporsi petani pengguna internet di DKI Jakarta nampaknya disebabkan posisinya sebagai ibukota provinsi yang sangat terekspos dengan kemajuan teknologi informasi dan komunikasi. Sementara itu, Banten merupakan provinsi yang memiliki proporsi petani pengguna internet terendah di Pulau Jawa, yakni hanya mencapai 6,3 persen. Hanya terdapat dua provinsi yang memiliki proporsi petani pengguna internet di atas 15 persen, yaitu Kepulauan Riau (18,3 persen) dan DKI Jakarta. Namun, perlu menjadi catatan, jumlah petani di kedua provinsi tersebut relatif kecil jika dibandingkan jumlah petani di provinsi lainnya. Gambar 1 memperlihatkan bahwa mayoritas provinsi memiliki proporsi petani padi pengguna internet di bawah 13 persen sekaligus mengkonfirmasi ketimpangan penggunaan internet pada petani padi di Indonesia secara spasial.

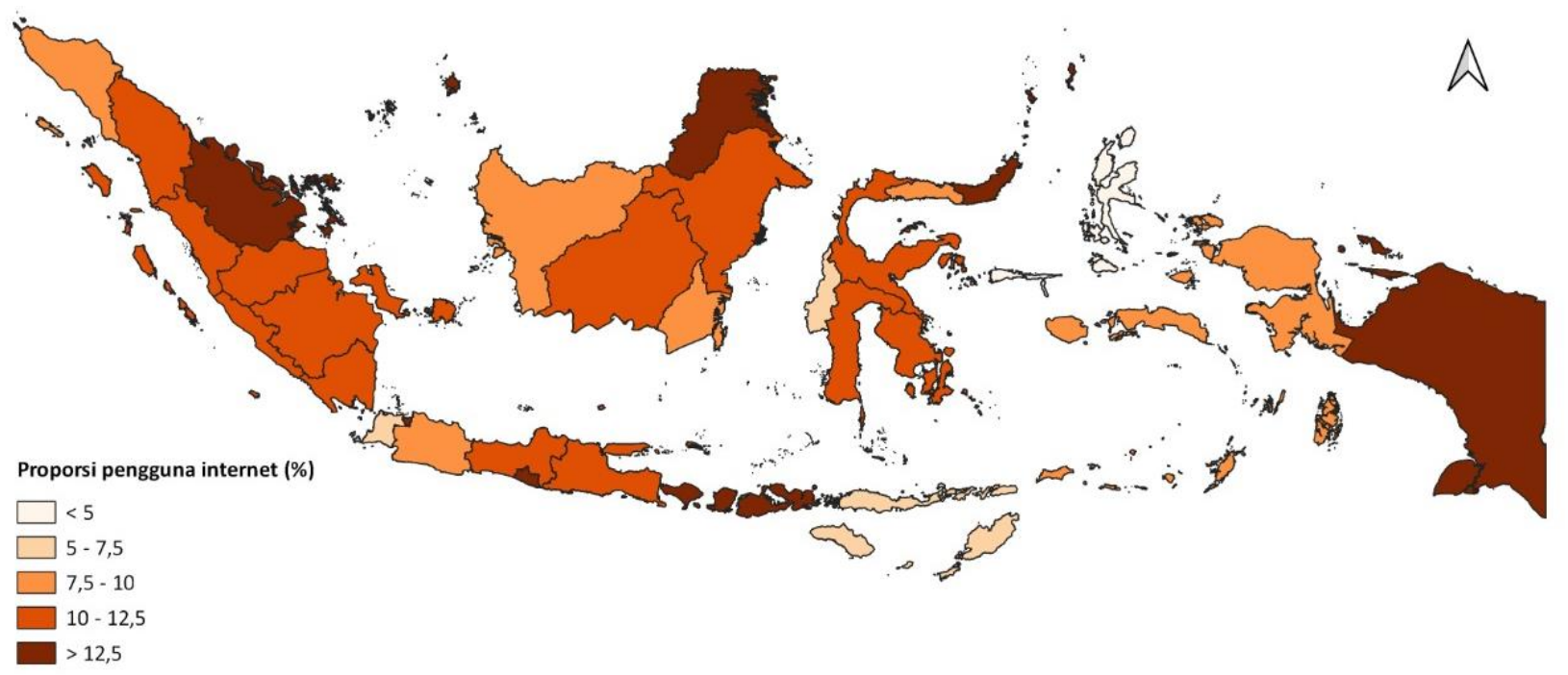

Gambar 1. Sebaran Petani Padi Pengguna Internet menurut Provinsi, 2018

Nampaknya, relatif rendahnya penggunaan internet di kalangan petani padi dapat dijelaskan dengan baik oleh karakteristik demografi petani padi yang dicirikan oleh pendidikan yang rendah dan rata-rata berumur tua. Hal ini mengantisipasi hasil estimasi model regresi logistik mengenai hubungan negatif antara penggunaan internet dengan umur dan hubungan positif antara peluang menggunakan internet dan tingkat pendidikan. 
Tabel 3. Sebaran Penggunaan Internet menurut Karakteristik Petani Padi di Indonesia (\%)

\begin{tabular}{lrr}
\hline \multicolumn{1}{c}{ Karakteristik petani padi } & Menggunakan internet & Tidak menggunakan internet \\
\hline 1. Kelompok umur (tahun) & & \\
$<30$ & 33,96 & 66,04 \\
$30-34$ & 27,76 & 72,24 \\
$35-39$ & 22,40 & 77,60 \\
$40-44$ & 15,53 & 84,47 \\
$45-49$ & 11,64 & 88,36 \\
$50-54$ & 7,35 & 92,65 \\
$55+$ & 3,18 & 96,82 \\
2. Tingkat pendidikan yang ditamatkan & & \\
Tidak sekolah/tidak tamat SD & 2,35 & 97,65 \\
SD & 5,43 & 94,57 \\
SMP & 17,03 & 82,97 \\
SMA & 30,30 & 69,70 \\
D1/D2 & 33,11 & 66,89 \\
D3 & 48,1 & 51,91 \\
D4/S1 & 61,27 & 38,73 \\
S2/S3 & 70,76 & 29,24 \\
3. Jenis kelamin & & \\
Laki-laki & 11,42 & 88,58 \\
Perempuan & 6,05 & 93,95 \\
4. Wilayah & & 89,61 \\
Jawa & 11,09 & 88,91 \\
Luar Jawa & 10,39 & \\
5. Jenis Varietas Padi yang Dibudidayakan & & 92,08 \\
Padi ladang & 7,92 & 87,87 \\
Padi sawah hibrida & 12,13 & 89,06 \\
Padi sawah inbrida & 10,94 & 89,20 \\
6. Total petani padi & 10,80 & \\
Sumber: diolah dari hasil Survei Pertanian Antar Sensus 2018 & &
\end{tabular}

Sumber: diolah dari hasil Survei Pertanian Antar Sensus 2018

\section{Determinan demografi penggunaan internet}

Hasil estimasi model regresi logistik pada Tabel 4 memperlihatkan bahwa gender, kelompok umur, tingkat pendidikan, dan wilayah tempat tinggal merupakan determinan demografi penggunaan internet oleh petani padi di Indonesia. Keempat variabel tersebut berdampak signifikan pada tingkat signifikansi 5 persen terhadap peluang petani dalam menggunakan internet.

Tabel 4. Hasil Estimasi Regresi Logistik

\begin{tabular}{|c|c|c|}
\hline Variabel tak bebas: penggunaan internet & Koefisien regresi & Odd ratio \\
\hline Jenis kelamin (laki-laki) & $0,1951^{* * *}$ & $1,2154 * * *$ \\
\hline Jenıs kelamın (lakı-lakı) & $(0,0201)$ & $(0,0244)$ \\
\hline \multicolumn{3}{|l|}{ Kelompok umur } \\
\hline $30-34$ & $\begin{array}{r}-0,3181 * * * \\
(0,0226)\end{array}$ & $\begin{array}{r}0,7276 * * * \\
(0,0164)\end{array}$ \\
\hline $35-39$ & $\begin{array}{r}-0,5905^{* * * *} \\
(0,0212)\end{array}$ & $\begin{array}{r}0,5540 * * * \\
(0,0117)\end{array}$ \\
\hline $40-44$ & $\begin{array}{r}-1,0061 * * * \\
(0,0214)\end{array}$ & $\begin{array}{r}0,3657 * * * \\
(0,0078)\end{array}$ \\
\hline $45-49$ & $\begin{array}{r}-1,3976 * * * \\
(0,0218)\end{array}$ & $\begin{array}{r}0,2472 * * * \\
(0,0054)\end{array}$ \\
\hline $50-54$ & $\begin{array}{r}-1,8542 * * * \\
(0,0237)\end{array}$ & $\begin{array}{r}0,1566 * * * \\
(0,0037)\end{array}$ \\
\hline $55+$ & $\begin{array}{r}-2,4503 * * * \\
(0,0234)\end{array}$ & $\begin{array}{r}0,0863 * * * \\
(0,0020)\end{array}$ \\
\hline \multicolumn{3}{|l|}{ Tingkat pendidikan } \\
\hline SD & $\begin{array}{r}0,4006^{* * * *} \\
(0,0208)\end{array}$ & $\begin{array}{r}1,4927 * * * \\
(0,0310)\end{array}$ \\
\hline SMP & $\begin{array}{r}1,3515^{* * *} \\
(0,0215)\end{array}$ & $\begin{array}{r}3,8631 \text { *** } \\
(0,0828)\end{array}$ \\
\hline SMA & $2,2405^{* * *}$ & $9,3981 * * *$ \\
\hline
\end{tabular}




\begin{tabular}{|c|c|c|}
\hline Variabel tak bebas: penggunaan internet & Koefisien regresi & Odd ratio \\
\hline \multirow{3}{*}{ D1/D2 } & $(0,0210)$ & $(0,1971)$ \\
\hline & $2,8221 * * *$ & $16,8127 * * *$ \\
\hline & $(0,0575)$ & $(0,9662)$ \\
\hline \multirow{2}{*}{ D3 } & $3,3569 * * *$ & $28,6993 * * *$ \\
\hline & $(0,0545)$ & $(1,5648)$ \\
\hline \multirow{2}{*}{$\mathrm{D} 4 / \mathrm{S} 1$} & $3,8668 * * *$ & $47,7908 * * *$ \\
\hline & $(0,0287)$ & $(1,3708)$ \\
\hline \multirow{2}{*}{$\mathrm{S} 2 / \mathrm{S} 3$} & $4,4755^{* * *}$ & $87,8384 * * *$ \\
\hline & $(0,1146)$ & $(10,0680)$ \\
\hline \multicolumn{3}{|l|}{ Jenis varietas } \\
\hline \multirow{2}{*}{ Padi sawah hibrida } & $0,2469 * * *$ & $1,2800 * * *$ \\
\hline & $(0,0254)$ & $(0,0325)$ \\
\hline \multirow{2}{*}{ Padi sawah inbrida } & $0,1378 * * *$ & $1,1477 * * *$ \\
\hline & $(0,0179)$ & $(0,0206)$ \\
\hline \multirow{2}{*}{ Wilayah (Jawa) } & $0,7712 * * *$ & $2,1624 * * *$ \\
\hline & $(0,0106)$ & $(0,0230)$ \\
\hline \multirow{2}{*}{ Logaritma natural luas panen } & $0,1273 * * *$ & $1,1357 * * *$ \\
\hline & $(0,0054)$ & $(0,0062)$ \\
\hline \multirow{2}{*}{ Konstanta } & $-3,9007 * * *$ & $0,0202 * * *$ \\
\hline & $(0,0619)$ & $(0,0013)$ \\
\hline
\end{tabular}

Prob > Chi $2=0,0000$

Pseudo $\mathrm{R}^{2}=0,2383$

Catatan: jumlah observasi 1.310.839; penimbang survei digunakan untuk estimasi; *** signifikan pada $\alpha=1 \%$; robust standard error disajikan dalam kurang

Petani padi laki-laki cenderung lebih berpeluang menggunakan internet dibanding petani perempuan, di mana kemungkinan petani laki-laki menggunakan internet 1,2 kali lebih besar dibanding petani perempuan. Hasil estimasi model mengkonfirmasi indikasi bahwa penggunaan internet oleh petani padi merupakan fenomena petani muda. Hasil estimasi memperlihatkan bahwa peluang petani padi untuk menggunakan internet semakin menurun seiring dengan peningkatan umur petani. Petani padi pada kelompok umur di bawah 30 tahun paling mungkin untuk menggunakan internet dibandingkan petani pada kelompok umur lainnya.

Tingkat pendidikan berdampak positif terhadap peluang petani untuk menggunakan internet. Semakin tinggi tingkat pendidikan, semakin besar peluang petani untuk menggunakan internet. Hasil estimasi memperlihatkan, kemungkinan petani padi dengan tingkat pendidikan yang ditamatkan sarjana dan pascasarjana untuk menggunakan internet masing-masing 47,8 kali dan 87,8 kali lebih besar dibanding petani padi yang tidak pernah sekolah atau tidak tamat SD. Temuan ini juga mengkonfirmasi bahwa selain merupakan fenomena petani muda, penggunaan internet pada petani padi juga merupakan fenomena petani berpendidikan tinggi.

Hasil estimasi model juga mengkonfirmasi bahwa faktor wilayah tempat tinggal petani berkontribusi signifikan terhadap peluang menggunakan internet. Petani padi di Pulau Jawa lebih berpeluang menggunakan internet dibanding petani di Luar Jawa. Hal ini boleh jadi dipengaruhi oleh perbedaan tingkat penetrasi internet di daerah pedesaan antara kedua wilayah, di mana akses internet di daerah pedesaan di wilayah Jawa secara umum lebih baik dibanding dengan wilayah di luar Jawa. Hasil estimasi memperlihatkan bahwa kemungkinan petani padi di Pulau Jawa untuk menggunakan internet 2,2 kali lebih besar dibanding petani padi di luar Jawa.

Jenis varietes padi yang dibudidayakan dan skala usaha tani, yang dicerminkan dengan luas panen padi dalam setahun, juga berdampak signifikan terhadap peluang petani padi untuk menggunakan internet. Petani yang membudidayakan tanaman padi sawah lebih mungkin menggunakan internet dibandingkan dengan petani padi ladang. Hasil estimasi memperlihatkan bahwa kemungkinan petani yang membudidayakan padi sawah hibrida dan inbrida untuk menggunakan internet masing-masing sebesar 1,3 kali dan 1,1 kali lebih besar dibandingkan dengan petani yang membudidayakan padi ladang. Sementara itu, skala usaha pertanian berdampak positif terhadap peluang petani padi menggunakan internet, semakin besar skala usaha pertanian yang diwakili oleh luas panen padi, semakin tinggi peluang petani padi menggunakan internet.

\section{Penggunaan internet dan produktivitas tanaman padi}

Hasil penelitian memperlihatkan bahwa terdapat perbedaan tingkat produktivitas tanaman padi antara kelompok petani yang menggunakan internet dan yang tidak menggunakan internet. Rata-rata produktivitas padi ladang dan padi sawah (hibrida dan inbrida) yang dibudidayakan oleh petani pengguna internet lebih tinggi dibandingkan dengan petani yang tidak menggunakan internet. 
Rata-rata produktivitas tanaman padi ladang, padi sawah hibrida, dan padi sawah inbrida yang dibudidayakan petani pengguna internet masing-masing sebesar 22,5 ku/ha, 46,1 ku/ha, dan 45,0 ku/ha. Sementara itu, rata-rata produktivitas tanaman padi ladang, padi sawah hibrida, dan padi sawah inbrida yang dibudidayakan petani yang tidak menggunakan internet, lebih rendah, yakni masing-masing sebesar 21,0 $\mathrm{ku} / \mathrm{ha}, 42,8 \mathrm{ku} / \mathrm{ha}$, dan 42,2 ku/ha.

Tabel 5. Produktivitas Tanaman Padi Sawah menurut Akses Penggunaan Internet (ku/ha)

\begin{tabular}{lrr}
\hline Jenis varietas padi & Menggunakan internet & Tidak menggunakan internet \\
\hline Padi ladang & 22,47 & 21,03 \\
- Rata-rata produktivitas & $22,00-22,95$ & $20,89-21,16$ \\
- Selang interval $(\alpha=5 \%)$ & & 42,82 \\
Padi sawah hibrida & 46,11 & $42,59-43,05$ \\
- Rata-rata produktivitas & $45,47-46,75$ & 42,16 \\
- Selang interval $(\alpha=5 \%)$ & & \\
Padi sawah inbrida & 45,01 & $42,11-42,22$ \\
- Rata-rata produktivitas & $44,86-45,16$ & 40,69 \\
- Selang interval $(\alpha=5 \%)$ & & 43,94 \\
Padi total & $43,80-44,09$ & $40,64-40,74$ \\
- Rata-rata produktivitas & &
\end{tabular}

Sumber: hasil perhitungan penulis berdasarkan hasil SUTAS 2018

Hasil estimasi selang interval rata-rata produktivitas padi pada tingkat signifikansi 5 persen (Tabel 5) dan Kernel Density Function distribusi produktivitas tanaman padi untuk setiap varietas yang dibudidayakan oleh kelompok petani pengguna internet dan kelompok petani yang tidak menggunakan internet (Gambar 2) menunjukkan bahwa perbedaan produktivitas antara kelompok pengguna internet dan bukan pengguna internet signifikan secara statistik. Plot Kernel Density Function memperlihatkan bahwa distribusi produktivitas padi kelompok petani pengguna internet terletak sedikit lebih ke kanan dari distribusi produktivitas kelompok petani bukan pengguna internet.

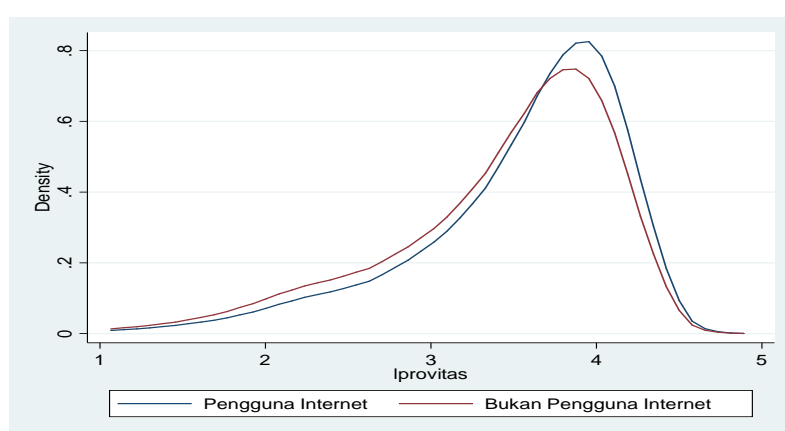

Padi

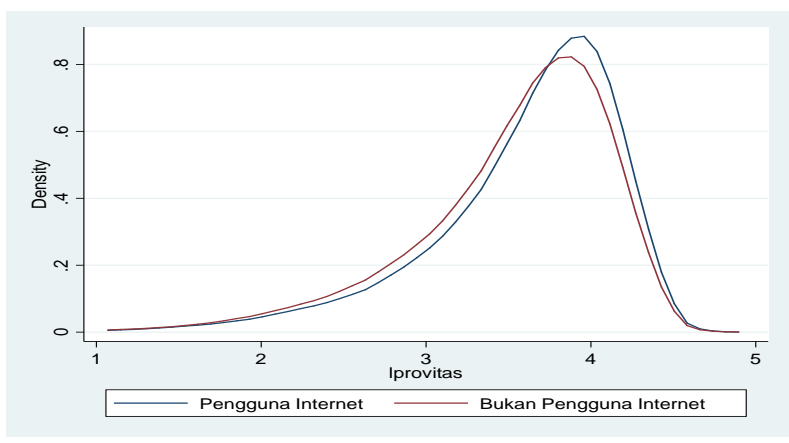

Padi Sawah Inbrida

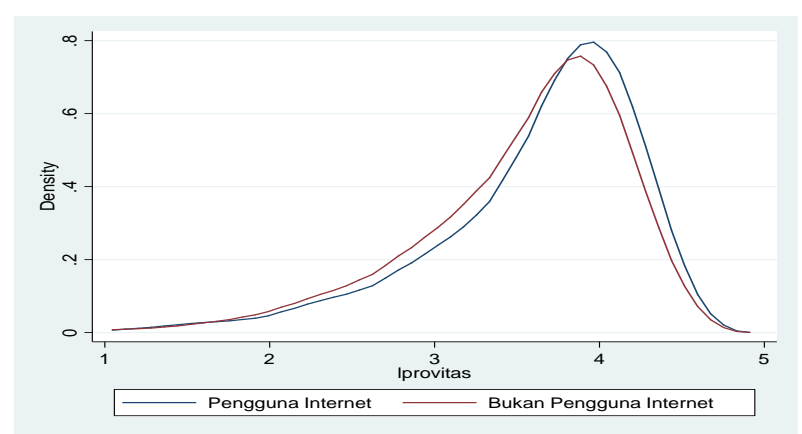

Padi Sawah Hibrida

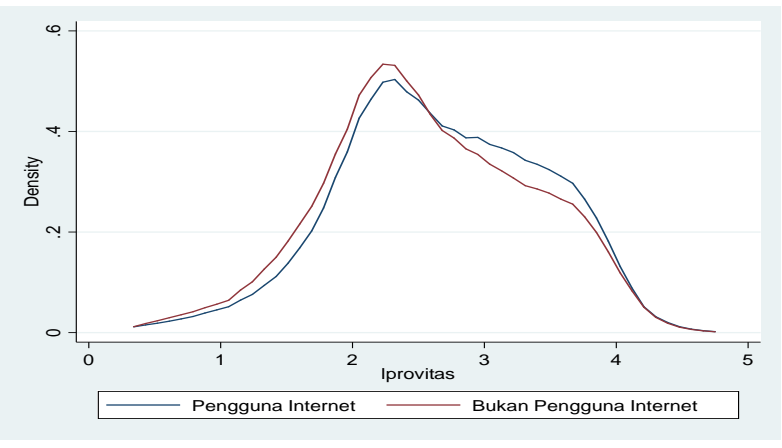

Padi Ladang

Gambar 2. Kernel Density Produktivitas Padi menurut Akses Internet Petani dan Jenis Varietas

Perbedaan produktivitas yang signifikan tersebut merupakan indikasi kuat bahwa penggunaan internet berdampak positif dan signifikan dalam meningkatkan produktivitas tanaman padi yang dibudidayakan oleh petani. Peningkatan produktivitas ini dapat terjadi, antara lain, karena petani pengguna internet memiliki akses 
yang lebih terhadap informasi mengenai teknologi budidaya dan kredit perbankan yang dapat digunakan untuk pengadaan sarana dan prasarana produksi sehingga mendukung upaya peningkatan produktivitas.

Studi lebih lanjut dibutuhkan untuk mengkonfirmasi apakah penggunaan internet berdampak pada peningkatan produksi tanaman padi yang dibudidayakan oleh petani. Terkait hal ini, penelitian mengenai hubungan antara penggunaan internet dan peningkatan output pertanian (dengan luas lahan yang sama/ceteris paribus) idealnya ditelaah dengan menggunakan fungsi produksi Cobb-Douglas yang dijadikan sebagai patokan standar dalam mengestimasi fungsi produksi (Griliches, 1957,1963) dengan mengikutkan variabel input produksi dan modal (lahan) ke dalam spesifikasi model. Dengan kerangka konseptual ini, akses terhadap internet masuk ke dalam spesifikasi model melalui total factor productivity (TFP) yang tidak terjelaskan. Contoh aplikasi empiris terkait hal ini adalah penelitian Kaila et.al (2018) untuk kasus Vietnam. Dalam penelitian ini kerangka konseptual tersebut tidak dapat diterapkan mengingat keterbatasan data mengenai input produksi dan modal yang tidak dicakup dalam kuesioner SUTAS 2018.

\section{KESIMPULAN}

Penelitian ini bertujuan mengidentifikasi variabel demografi yang merupakan determinan penggunaan internet oleh petani padi di Indonesia dengan mengelaborasi hasil SUTAS yang dilaksanakan BPS pada tahun 2018. Selain itu, penelitian ini juga bertujuan untuk menelaah kaitan antara penggunaan internet dan tingkat produktivitas usaha budidaya tanaman padi. Hasil estimasi model regresi logistik memperlihatkan bahwa gender, umur, pendidikan, dan wilayah tempat tinggal petani padi berdampak signifikan terhadap peluang petani padi untuk menggunakan internet. Penggunaan internet di kalangan petani padi merupakan fenomena petani muda (kelompok usia di bawah 40 tahun), berpendidikan tinggi (minimal sarjana), laki-laki, dan tinggal di Pulau Jawa. Sayangnya, petani padi dengan kombinasi karakteristik demografi seperti ini hanya mewakili kelompok kecil petani padi Indonesia. Hasil penelitian juga memperlihatkan bahwa skala usaha tani padi yang dijalankan berdampak positif dan signifikan terhadap peluang penggunaan internet, di mana semakin tinggi skala usaha tani padi, semakin tinggi peluang petani menggunakan internet.

Terkait kaitan antara penggunaan internet dan tingkat produktivitas, hasil penelitian ini mengonfirmasi bahwa rata-rata produktivitas tanaman padi yang dibudidayakan oleh petani pengguna internet lebih tinggi secara signifikan dibandingkan dengan petani bukan pengguna internet. Hal ini merupakan indikasi kuat bahwa penggunaan internet oleh petani berdampak positif terhadap peningkatan produktivitas. Namun demikian, penelitian lebih lanjut yang didasarkan pada kerangka teoritis fungsi produksi (Cobb-Douglas) dibutuhkan untuk mengkonfirmasi bahwa penggunaan internet berdampak positif terhadap peningkatan output petani padi (peningkatan produktivitas).

Mengingat masih rendahnya penggunaan internet di kalangan petani padi yang masih sekitar 11 persen dari total petani padi dan hubungan positif antara penggunaan internet dan tingkat produktivitas tanaman padi, pemerintah sebaiknya meningkatkan penetrasi internet melalui penyediaan infrastruktur pendukung di wilayah pedesaan sehingga dapat menjangkau petani padi dalam skala yang lebih luas.

\section{DAFTAR PUSTAKA}

Bogdan, R., \& Biklen, S. K. (2007). Qualitative Research for Education; An Introduction to Theories and Models. (5th ed.). Pearson.

BPS. (2019). Luas Panen dan Produksi Padi di Indonesia 2019. Badan Pusat Statistik.

BPS. (2021). Analisis Produktivitas Padi di Indonesia 2020: Hasil Survei Ubinan. Badan Pusat Statistik.

D, S., \& NL, R. (2020). Prerequisite for Growth: ICT Usage in Secondary Education in Bosnia and Herzegovina. Infoteh-Jahorina, 9(8), 1028-1030.

FAO. (2010). Handbook on crop statistics: improving methods for measuring crop area, production and yield. fao.org

Greene, W. H. (2002). Econometric Analysis (5th ed.). Prentice Hall.

Griliches, Z. (1957). Specification Bias in Estimates of Production Functions. Journal of Farm Economics, $39(1), 8-20$.

Griliches, Z. (1963). Estimates of the Aggregate Agricultural Production Function from Cross-Sectional Data. Journal of Farm Economics, 45(2), 419-428.

Hill, R. A., Davies, P. B., \& Williams, M. D. (2008). Older people and internet engagement: Acknowledging social moderators of internet adoption, access and use. Information Technology \& People, 21(3), 244266.

Kaila, H., \& Tarp, F. (2019). Can the Internet improve agricultural production? Evidence from Viet Nam. 
Agricultural Economics (United Kingdom), 50(6), 675-691. https://doi.org/10.1111/agec.12517

Khanal, A. R., \& Mishra, A. K. (2013). Assessing the impact of internet access on household income and financial performance of small farms. Southern Agricultural Economics Association (SAEA), February, 3-5. http://ageconsearch.umn.edu/bitstream/143019/1/SAEA_paper_Aditya_re_18Jan.pdf

LoPiccalo, K. (2021). Impact of Broadband Penetration on U.S. Farm Productivity. SSRN Electronic Journal. https://doi.org/10.2139/ssrn.3790850

Mishra, A., \& Williams, R. P. (2006). Internet access and use by farm households. 2006 Annual Meeting, July 23-26, Long, 1-30. http://ideas.repec.org/p/ags/aaea06/21106.html

Ruslan, K. (2021). Food and Horticulture Crop Productivity in Indonesia (Issue 37). https://repository.cipsindonesia.org/publications/346216/food-and-horticulture-crop-productivity-in-indonesia

Safitri, L. S. (2020). Pemanfaatan Teknologi Informasi dan Komunikasi Dalam Mengakses Kredit Bagi Petani. The World of Business Administration Journal, 1(2), 125-142. https://doi.org/10.37950/wbaj.vi.750

Sekabira, H., Bonabana, J., \& Asingwire, N. (2012). Determinants for Adoption of ICT-Based Market Information Services by Smallholder Farmers and Traders in Mayuge District, Uganda Determinants for adoption of information and communications technology ( ICT ) -based market information services by smallhol. Journal of Development and Agricultural Economics Vol., 4(March), 404-415. https://doi.org/10.5897/JDAE12.081

Van Kerm, P. (2003). Adaptive Kernel Density Estimation. The Stata Journal: Promoting Communications on Statistics and Stata, 3(2), 148-156. https://doi.org/10.1177/1536867x0300300204

Warren, M. (2003). Farmers and The Internet, six years on. EFITA 2003 Conference, August 2003, 643-650. 